\title{
IoT-based Intelligent Fishcarelab System (IFS) for Koi Fish Monitoring System
}

\author{
Minto Waluyo ${ }^{1}$, Basuki Rahmat ${ }^{2}$, Tuhu Agung \\ Rachmanto ${ }^{3}$, Mohamad Irwan Afandi ${ }^{4}$, Helmy \\ Widyantara ${ }^{5}$ \\ Universitas Pembangunan Nasional "Veteran" Jawa Timur, \\ Surabaya, Indonesia \\ ${ }^{1}$ mintowaluyo_ti@yahoo.co.id
}

\author{
Harianto $^{6}$ \\ Computer System Department \\ Institut Bisnis dan Informatika STIKOM Surabaya, \\ Surabaya, East Java, Indonesia
}

\begin{abstract}
Internet of Things (IoT) allows connections between devices using an internet connection with the ability to collect and exchange data. This research utilizes the IoT network to monitor the growth of koi fish in the pond. By utilizing the NodeMCU microcontroller, temperature and $\mathrm{pH}$ sensors, the sensor readings can be sent to the IoT cloud. Finally, by logging into the IoT cloud, the temperature and $\mathrm{pH}$ readings curve in the pond can be displayed.
\end{abstract}

Keywords - Internet of Things; IoT; Intelligent; Fishcarelab; IFS; koi; Cyprinus carpio.

\section{INTRODUCTION}

Internet of Things (IoT) is a network of physical devices, vehicles, household appliances, and other items embedded in electronics, software, sensors, actuators, and connectivity that allow these things to connect and exchange data [1],[2]. The existence of IoT creates opportunities for direct integration of the physical world into computer-based systems, which results in increased efficiency, economic benefits, and a reduction in the mobilization of human resources [3]

Further understanding of IoT is an ecosystem consisting of devices equipped with sensor technology, computing, and networks that collaborate to create an autonomous environment where intelligent services are delivered to improve the quality of human life. Common application domains where the IoT concept is currently being explored and utilized include conservation and management of electrical energy, transportation, health, logistics, urban life, education, etc [4].

Utilization of IoT networks for the purpose of enhancing empowerment in agriculture, among others can be mentioned [5]-[8]. Likewise, the use of IoT for exploitation and preservation of natural resources under the sea including fisheries, was carried out by previous researchers, among others [9]. This research itself intends to utilize the IoT network to monitor the growth of koi fish (Cyprinus carpio). This research is a continuation of previous research, namely Designing Intelligent Fishcarelab System (IFS) as Modern Koi Fish Farming System [9].

As is generally known, in the cultivation of koi fish must always be monitored in its growth. Growth is an increase in length or weight in a certain time [10]. Fish growth is influenced by internal and external factors. Internal factors are: body weight, sex, age, fertility, health, movement, acclimation, biomass activity, and oxygen consumption. While external factors consist of abiotic factors and biotic factors. Abiotic factors consist of pressure, temperature, salinity, water oxygen content, metabolite discharge $\left(\mathrm{CO}_{2}, \mathrm{NH}_{3}\right), \mathrm{pH}$, light, season [11]. In this research only limited monitoring of external factors of temperature and $\mathrm{pH}$. Which further monitoring will utilize the IoT network.

The research of monitoring the growth of koi fish is very interesting, because of the beauty of various types of koi fish in the world. There are so many researches related to the cultivation of koi fish and how to maintain an ideal living environment and strive to make the color ornaments beautiful and pleasing to those who see them, some researches include [12]-[17]. Some types of beautiful and famous koi fish in the world, among others:

\section{Kohaku}

Kohaku koi fish is a type of koi fish which has red and white hues. The color of this koi has various color patterns. There are red ones that break, some are wide, and some are sweeping. A quality kohaku koi is a koi that has a white color like snow and a dark red color, as shown in Fig. 1.

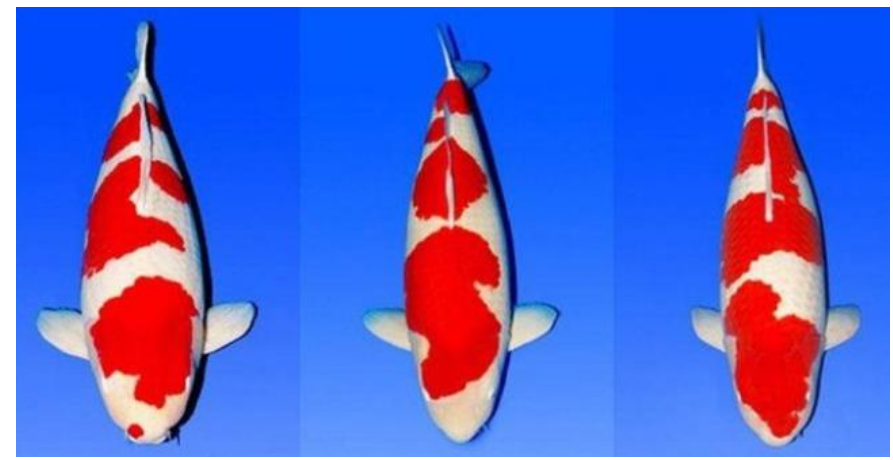

Fig. 1. Kohaku koi fish

Showa

Showa koi fish has 3 color combinations on the scales, namely red, black and white. Showa koi fish is the result of 
crossing from koi shiro utsuri fish with koi kohaku fish, as shown in Fig. 2.

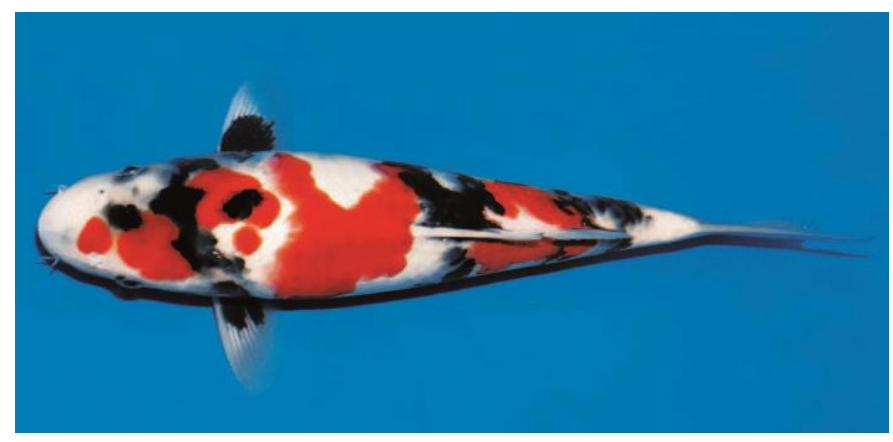

Fig. 2. Showa Koi Fish

Sanke

Sanke koi fish has a color that is almost similar to the kohaku which is red and white. What distinguishes the two types of koi fish is that there is a black color along the back of the koi sanke. Quality Sanke Koi are koi that do not have black on the head, as shown in Fig. 3.

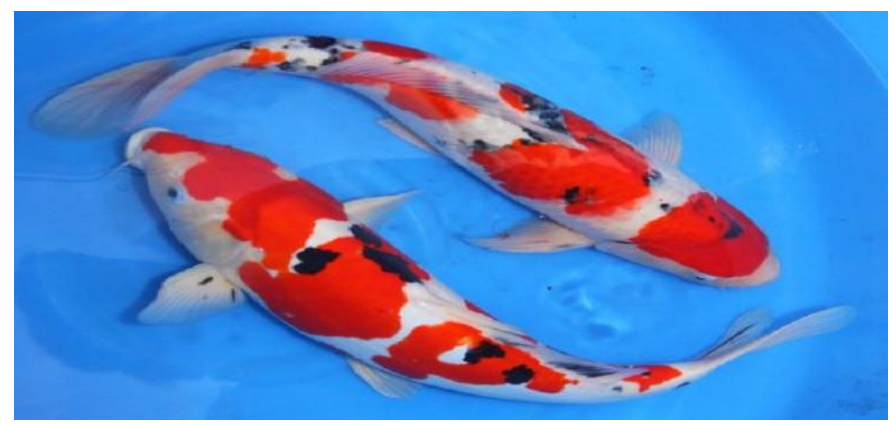

Fig. 3. Sanke Koi Fish

Asagi

Koi fish asagi is a type of koi fish which has a white base color with a combination of red or orange in the abdomen, gills, fins and body. Red or orange will develop with age. This fish has a unique pattern like a net at the top. This fish is included in the type of koi that has long existed, as shown in Fig. 4.

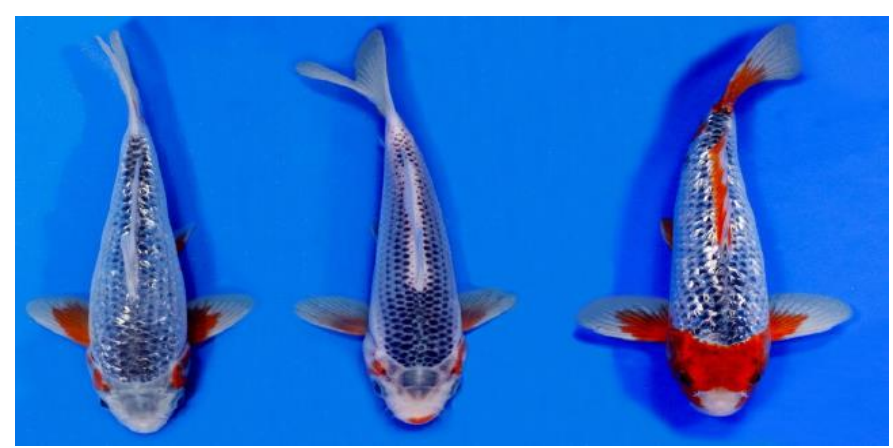

Fig. 4. Asagi Koi Fish

\section{Shusui}

Shusui koi fish has a white base color that is covered in red or orange wide. This fish has a scaly pattern along a dark back. Shusui Koi Fish have similar colors like Asagi. The thing that distinguishes between Shusui and Asagi is that Shusui has a line pattern along the back, while Asagi has a blue mesh pattern on his back, as shown in Fig. 5 .

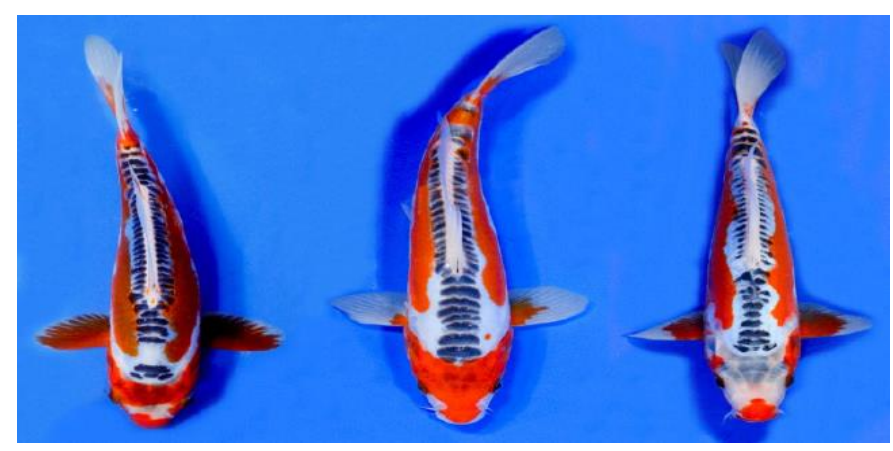

Fig. 5. Shusui Koi Fish

\section{Tancho}

Tancho koi fish is the most popular type of koi fish among other types of koi fish, even the popularity of this type of fish defeats kohaku. Tancho Koi fish has a white color with a red round pattern on the head. Placement of the pattern on his head shows the quality of the fish, as shown in Fig. 6.

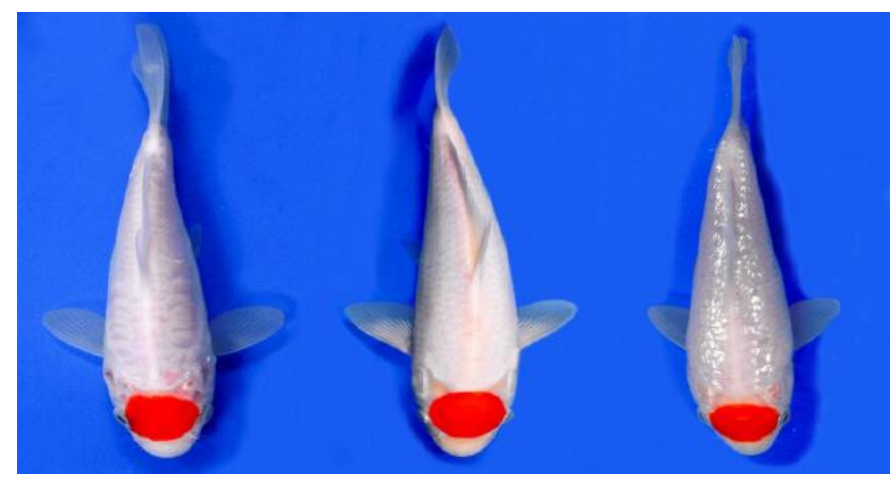

Fig. 6. Tancho Koi Fish

\section{TEMPERATURE AND PH REQUIREMENTS}

\section{Temperature}

Koi fish is a cold-blooded animal, so that its body temperature depends on the temperature of the water as its environment. Koi fish can live in a temperature range of 0 $35^{\circ} \mathrm{C}$, but at too extreme temperatures this fish will stop eating and its immune system will disappear. While the ideal temperature for koi fish is $15-25^{\circ} \mathrm{C}$. Temperature changes that are too drastic can cause stress.

\section{Degree of acidity $(p H)$}

Most koi fish can adapt well to aquatic environments that have a degree of acidity $(\mathrm{pH})$ ranging from 5-9. The ideal $\mathrm{pH}$ for koi fish to grow healthy is around 6.5-8.5. At night biota in water will do respiration and produce carbon dioxide $\left(\mathrm{CO}_{2}\right)$ which can reduce $\mathrm{pH}$, while during the day algae will do photosynthesis which will produce oxygen and neutralize $\mathrm{pH}$, therefore the water $\mathrm{pH}$ in the morning tends to be low while during the day $\mathrm{pH}$ tends to be more stable. 


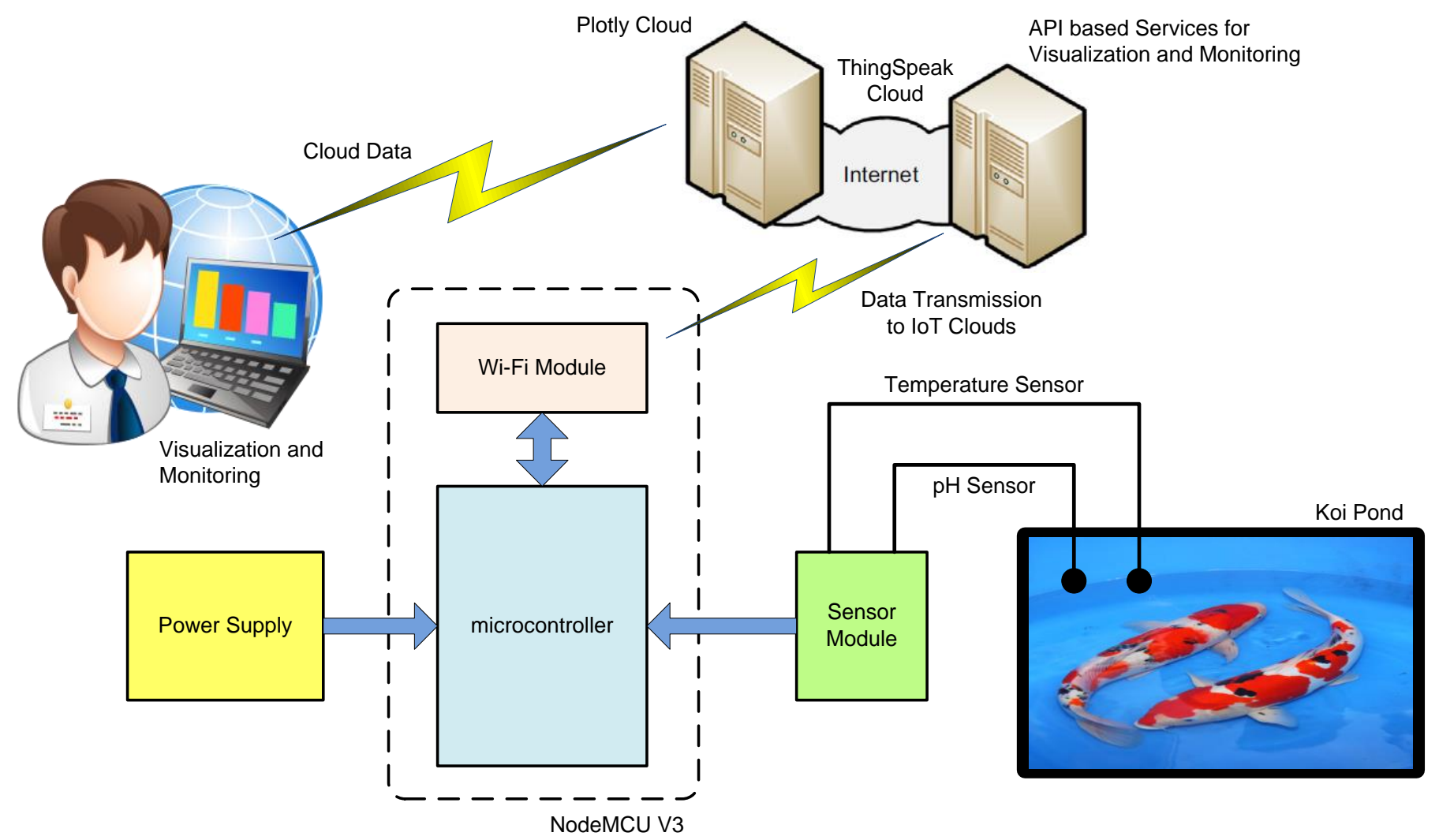

Fig. 7. IoT-based Intelligent Fishcarelab System (IFS) Architecture

\section{Proposed Methodology}

\section{A. System Architecture}

The main control brain of this system is the NodeMCU V3 microcontroller. NodeMCU is an electronic board based on the ESP8266 chip with the ability to run microcontroller functions and also an internet connection (WiFi). There are several I / O pins so that it can be developed into a monitoring and controlling application on IoT projects.

The microcontroller is designed to read the sensor module, which consists of a temperature sensor and $\mathrm{pH}$ sensor. These sensors will read the temperature and $\mathrm{pH}$ of the water in the pond where the koi fish live. Then through the Wifi module, the microcontroller can communicate with IoT cloud. The microcontroller transmits data to IoT cloud, in this case thingspeak.com.

Furthermore, IoT is equipped with an Application Program Interface (API) based services for visualization and monitoring. Visualization and monitoring of readings from the temperature and $\mathrm{pH}$ sensor in the koi pond, can be accessed via a computer connected to the internet. The proposed IoT-based Intelligent Fishcarabab System (IFS) architecture is designed as in Fig. 7.

\section{B. NodeMCU Pin Configuration}

NodeMCU is an eLua based firmware for ESP8266 WiFi SOC from Espressif. The NodeMCU firmware is a companion project for the popular NodeMCU dev kit, an open source development board ready to use with the ESP8266-12E chip [18].
The NodeMCU is equipped with a micro usb port that functions for both powering and power supply. In addition, the NodeMCU is equipped with a push button, the reset and flash buttons. NodeMCU uses the Lua programming language which is a package from esp8266. Lua has logic and the same arrangement of $\mathrm{c}$ with different syntax. Lua language programming can be done by using the Lua loader and Lua uploder tool. In addition to the Lua NodeMCU language also supports the Arduino IDE software with a slight change in the board manager on the Arduino IDE. NodeMCU V3 pin configuration as shown in Fig. 8.

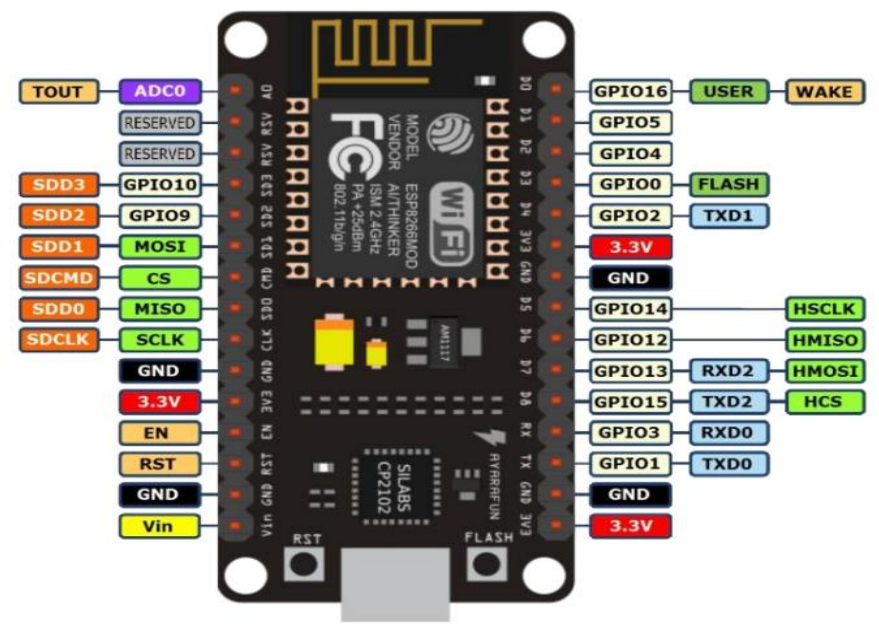

Fig. 8. NodeMCU V3 Pin Configuration 


\section{RESUlTS AND DISCUSSION}

The koi pond used in this experiment is shown in Fig. 9. The same pond used in previous research [18]. The temperature sensor and pH sensor used are shown in Fig. 10 and Fig. 11.

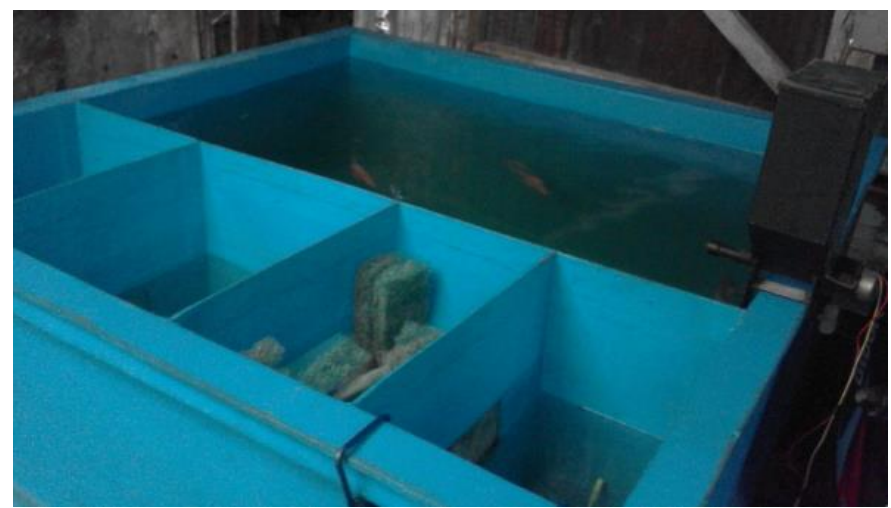

Fig. 9. Koi Pond

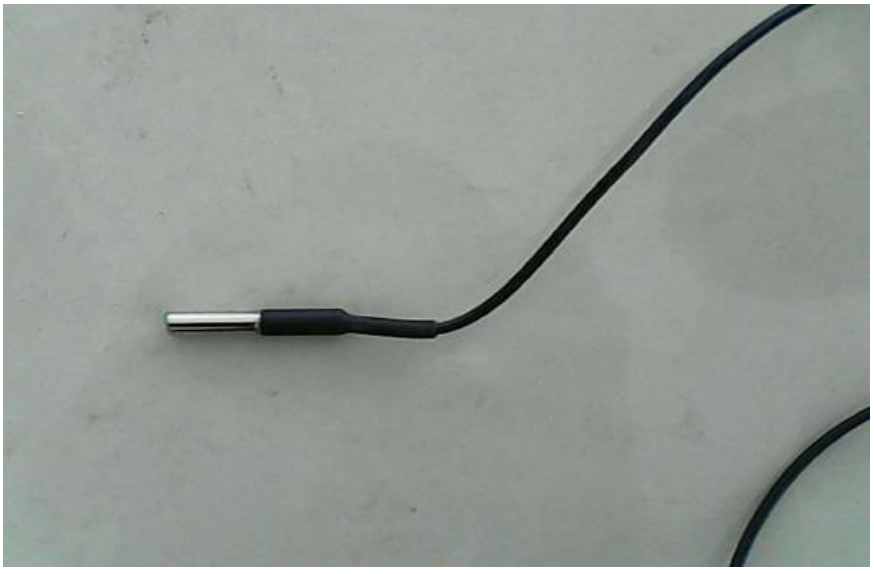

Fig. 10. Temperature Sensor

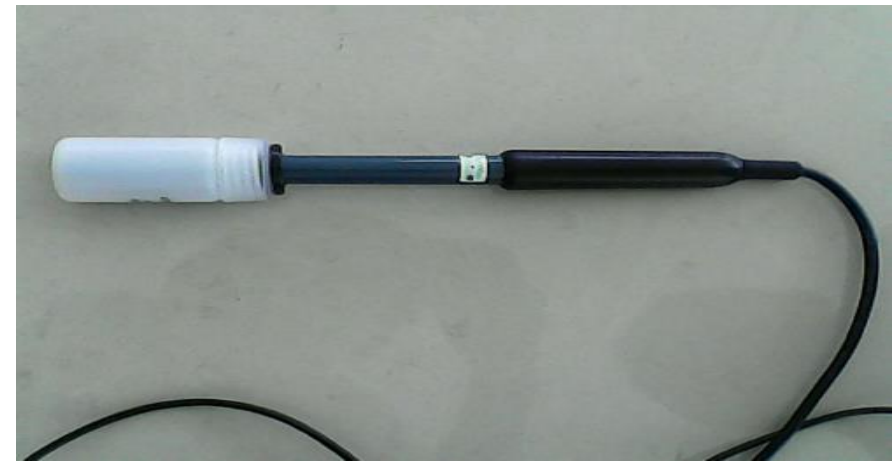

Fig. 11. pH Sensor

The results of the temperature and $\mathrm{pH}$ sensor readings from the previous research can be seen in Table I. [18]. From the results of logging into the IoT cloud (thingspeak.com), the results are expected as shown in Fig. 12. There are similarities with the results of previous research, which without connection to the IoT network.

TABLE I. READINGS OF TEMPERATURE AND PH SENSORS

\begin{tabular}{|c|c|}
\hline Temperature $\left.{ }^{\circ} \mathbf{C}\right)$ & $\mathbf{p H}$ \\
\hline 27.87 & 8.2 \\
\hline 27.87 & 8.2 \\
\hline 27.87 & 8.17 \\
\hline 27.81 & 8.17 \\
\hline 27.81 & 8.16 \\
\hline 27.81 & 8.16 \\
\hline 27.75 & 8.16 \\
\hline 27.75 & 6.98 \\
\hline 27.69 & 6.98 \\
\hline 27.69 & 6.98 \\
\hline
\end{tabular}

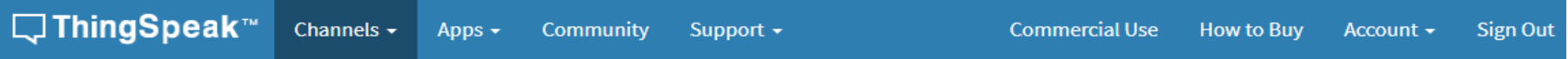

\section{Channel Stats}

Created: 6months.ago

Updated: 6months.ago

Last entry: 6.months.ago

Entries: 252
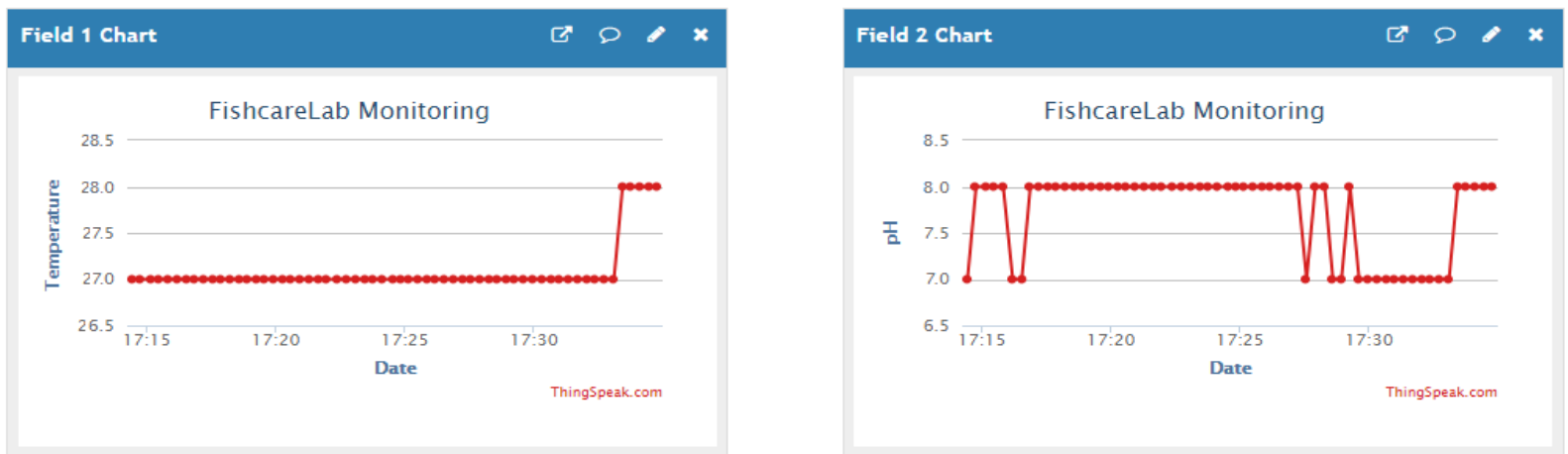

Fig. 12. Temperature and $\mathrm{pH}$ monitoring results 


\section{CONCLUSION}

From the experimental results it can be shown that the NodeMCU microcontroller can be used to communicate with the IoT cloud. This microcontroller is equipped with temperature and $\mathrm{pH}$ sensors, which are used to determine the temperature and $\mathrm{pH}$ of the water in the koi pond. If an internet connection is available, and can log into the IoT cloud, then the temperature and $\mathrm{pH}$ readings curve in the pond can be displayed.

\section{ACKNOWLEDGMENT}

We are grateful to Directorate General of Higher Education of Indonesia for research funding in accordance with DIPA Directorate General of Research and Development Strengthening, Ministry of Research, Technology and Higher Education, Number SP DIPA-042.06.1.401516/2017, dated December 6, 2016.

\section{REFERENCES}

[1] E. Brown, Who Needs the Internet of Things? 2016.

[2] B. Rahmat, T.A. Rachmanto, M. Waluyo, M.I. Afandi, H. Widyantara, and H. Harianto, "Designing Intelligent Fishcarelab System (IFS) as modern koi fish farming system," in Technology of Information and Communication (ISemantic), International Seminar on Application for, pp. 142-148, 2016.

[3] P.V. Ovidiu; Friess, Internet of Things: Converging Technologies for Smart Environments and Integrated Ecosystems, 2013.

[4] O. Bello and S. Zeadally, "Toward Efficient Smartification of The Internet of Things (IoT) Services,” Futur. Gener. Comput. Syst., 2017.

[5] A. Tzounis, N. Katsoulas, T. Bartzanas, and C. Kittas, "Internet of Things in Agriculture, Recent Advances and Future Challenges," Biosyst. Eng., vol. 164, pp. 31-48, 2017.

[6] F.J. Ferrández-Pastor, J.M. García-Chamizo, M. Nieto-Hidalgo, J. Mora-Pascual, and J. Mora-Martínez, "Developing Ubiquitous Sensor Network Platform Using Internet of Things: Application in Precision Agriculture," Sensors, 16(7), 2016.

[7] A Çaylı, A. Akyüz, A.N. Baytorun, S. Boyacı, S. Üstün, and F.B. Kozak, "Control of Greenhouse Environmental Conditions with IOT Based Monitoring and Analysis System,” Turkish J. Agric. - Food Sci.
Technol., vol. 5(11), pp. 1279-1289, 2017.

[8] J.M. Talavera, L.E. Tobón, J.A. Gómez, M.A. Culman, J.M. Aranda, D.T. Parra, L.A. Quiroz, A. Hoyos, and L. E. Garreta, "Review of IoT Applications in Agro-Industrial and Environmental Fields," Comput. Electron. Agric., vol. 142, pp. 283-297, 2017.

[9] M.C. Domingo, "An overview of the internet of underwater things," J. Netw. Comput. Appl., 35(6), pp. 1879-1890, 2012.

[10] M.I. Effendie, "No Title," in Biologi Perikanan, 1997.

[11] J. R. B. W. S. D. J. R. Hoar, "No Title," vol. 8, 1979.

[12] C. Vergneau-Grosset, N. Summa, C.O. Rodriguez, A. Cenani, M.F. Sheley, M.A. McCarthy, J.C.M. Tanner, K.L. Phillips, G.B. Hunt, and J.M. Groff, "Excision and Subsequent Treatment of a Leiomyoma from the Periventiduct of a Koi (Cyprinus carpio koi)," J. Exot. Pet Med., 25(3), pp. 194-202, 2016.

[13] J. Mayer, P. Hensel, J. Mejia-Fava, J. Brandão, and S. Divers, "The Use of Lufenuron to Treat Fish Lice (Argulus sp) in Koi (Cyprinus carpio)," J. Exot. Pet Med., 22(1), pp. 65-69, 2013.

[14] R. Kumar, T.R. Swaminathan, R.G. Kumar, A. Dharmaratnam, V.S. Basheer, and J.K. Jena, "Mass mortality in ornamental fish, Cyprinus carpio koi caused by a bacterial pathogen, Proteus hauseri," Acta Trop., vol. 149, pp. 128-134, 2015.

[15] M.-F. Song, Y.-H. Kang, D.-X. Zhang, L. Chen, J.-F. Bi, H.-P. Zhang, L. Zhang, A.-D. Qian, and X.-F. Shan, "Immunogenicity of extracellular products from an inactivated vaccine against Aeromonas veronii TH0426 in koi, Cyprinus carpio," Fish Shellfish Immunol., vol. 81, pp. 176-181, 2018.

[16] Y. Wang, W. Zeng, Y. Li, H. Liang, C. Liu, H. Pan, P. Lee, S. Wu, S. M. Bergmann, and Q. Wang, "Development and Characterization of a Cell Line from The Snout of Koi (Cyprinus carpio L.) for Detection of Koi Herpesvirus," Aquaculture, vol. 435, pp. 310-317, 2015.

[17] P. Ouyang, R. Yang, J. Chen, K. Wang, Y. Geng, W. Lai, X. Huang, D. Chen, J. Fang, Z. Chen, L. Tang, and L. Yin, "First Detection of Carp Edema Virus in Association with Cyprinid Herpesvirus 3 in Cultured Ornamental Koi, Cyprinus carpio L., in China," Aquaculture, vol. 490, pp. 162-168, 2018.

[18] NodeMCU [Online], "NodeMCU Documentation," Available: https://nodemcu.readthedocs.io/en/master. 